\title{
Interactions between temperature, drought and stomatal opening in legumes
}

\author{
Christina E. Reynolds-Henne, Anita Langenegger, Jan Mani, Nicole Schenk, Anita Zumsteg, Urs Feller* \\ Institute of Plant Sciences (IPS) and Oeschger Centre for Climate Change Research (OCCR), University of Bern, Altenbergrain 21, CH-3013 Bern, Switzerland
}

\section{A R T I C L E I N F O}

\section{Article history:}

Received 20 March 2009

Received in revised form 5 November 2009

Accepted 8 November 2009

\section{Keywords:}

Drought

Temperature stress

Legume

Thermal imaging

\begin{abstract}
A B S T R A C T
The effect of heat and drought on stomatal behaviour of 2-4-week-old legumes, bean (Phaseolus vulgaris L.) and red clover (Trifolium pratense), was investigated. Drought stress was induced by complete water deficit or with polyethylene glycol (PEG), and abscisic acid (ABA) was applied to mimic plant drought response. Heat stress was simulated by water bath (leaf segments) and infrared and halogen lighting (whole plants). Various experimental conditions were studied: high temperature alone or combined with drought, and low or high photosynthetically active radiation (PAR). Stomatal opening was either measured directly or determined using thermal imaging as a proxy. When water was not limiting, stomata opened in darkness under heat stress. At high PAR, drought and moderate heat caused increased leaf temperatures and temperature oscillations $\left( \pm 3-4{ }^{\circ} \mathrm{C}\right)$, attributed to the opening and closing of stomata. At low PAR, heat led to leaf temperature oscillations in control plants, whereas the application of drought caused stomatal closure, increasing leaf temperature to $39^{\circ} \mathrm{C}$. Stomatal opening occurred under high temperatures, despite the presence of the drought-induced hormone $A B A$, and was maintained into a recovery period at room temperature for $30 \mathrm{~min}$. This study helps to illustrate stomatal plasticity and the interplay between leaf gas-exchange and maintaining favourable metabolic conditions (water status and temperature) within the leaf. Knowledge of how legumes are affected by two environmental stresses, heat and drought, expected to occur simultaneously with greater frequency in the future, is important in determining overall plant survival strategies.
\end{abstract}

(c) 2009 Elsevier B.V. All rights reserved.

\section{Introduction}

In both natural and agricultural settings, plants are exposed to environmental stress. Stress may develop over months (i.e. mineral nutrient stress), days to weeks (i.e. drought stress) or even minutes (i.e. temperature stress). Though plant stress is often viewed at the level of the whole plant (e.g. biomass production, yield or survival), initial responses to stress (e.g. changes in carboxylation efficiency, stomatal limitations, accumulation of protective solutes) occur at the leaf level (Haldimann and Feller, 2004; Flexas et al., 2004; Iriti et al., 2009). At the interface between atmosphere and plant, leaf stomata provide the entryway for $\mathrm{CO}_{2}$ for photosynthetic carbon fixation, while preventing excessive water loss. Through their role in transpiration, stomata also help control leaf temperature. Net stomatal conductance depends on both plant-specific traits, such as stomatal density, leaf age and size, sub-stomatal $\mathrm{CO}_{2}$ concentration, guard cell and epidermal cell turgor (Jones, 1992), and on signals received from the environment. There is ample evidence for the

Abbreviations: ABA, abscisic acid; PAR, photosynthetically active radiation; PEG, polyethylene glycol; Rubisco, ribulose-1,5-bisphosphate-carboxylase/-oxygenase; WD, water deficit.

* Corresponding author. Tel.: +4131631 4958; fax: +41316314942.

E-mail address: urs.feller@ips.unibe.ch (U. Feller). effects of light (e.g. Assmann and Shimazaki, 1999; Roelfsema et al., 2002), mesophyll photosynthesis (e.g. Wong et al., 1979; Zeiger and Field, 1982; Lawson, 2009), external $\mathrm{CO}_{2}$ concentration (e.g. Morison and Gifford, 1984; Saxe et al., 1998; Medlyn et al., 2001) and water status on stomata (e.g. Kappen et al., 1987; Mott et al., 1997; Wilkinson and Davies, 2002). However, knowledge of the effects of ambient temperature on stomata remains limited (Zeiger, 1983; Lu et al., 2000; Feller, 2006).

The daily temperature range experienced by plants varies greatly with cloudiness and wind strength (Gates, 1964), while soil moisture conditions are more temporally stable (Pachepsky et al., 2005; Teuling et al., 2007). On a seasonal scale, the frequency and severity of temperature and soil moisture extremes is expected to increase in the next decades (Schär et al., 2004; Meehl and Tebaldi, 2004; Ciais et al., 2005). Water deficit rarely acts alone (Chaves et al., 2002) and interactions between drought and high temperature on water relations, photosynthesis and crop growth have already been observed (Machado and Paulsen, 2001; Wardlaw, 2002; Shah and Paulsen, 2003). However, the combined impact of drought and high temperature on stomata is not well documented (Van Peer et al., 2004; Wang and Huang, 2004). When occurring separately, drought and heat have antagonistic effects on stomata. In general, stomata close rapidly under drought conditions. High temperatures may affect plant processes directly by injuring the photosynthetic apparatus (Law and Crafts-Brandner, 1999; Haldimann and Feller, 
2004), or indirectly through water relations by promoting evaporative water loss from the soil. In warm and moist environments, stomata have been shown to open wide (Radin et al., 1994; Feller, 2006; Veselova et al., 2006), while at low temperatures they tend to close (Eamus et al., 1982; Wilkinson et al., 2001; Veselova et al., 2006), incurring trade-offs between leaf cooling, favourable water status, gas-exchange and photosynthesis (Feller et al., 1998; Haldimann and Feller, 2004; Grassi and Magnani, 2005).
The present study addresses the question: how do stomata operate under short-term drought and high temperature in two legumes, bean (Phaseolus vulgaris L.) and red clover (Trifolium pratense)? Stomatal aperture was measured by light microscopy and thermal imaging, a proxy for stomatal conductance (Fuchs and Tanner, 1966; Smith et al., 1988). Understanding stomatal regulatory strategies, whether they favour plant productivity, leaf viability, or protect from injury to the photosynthetic

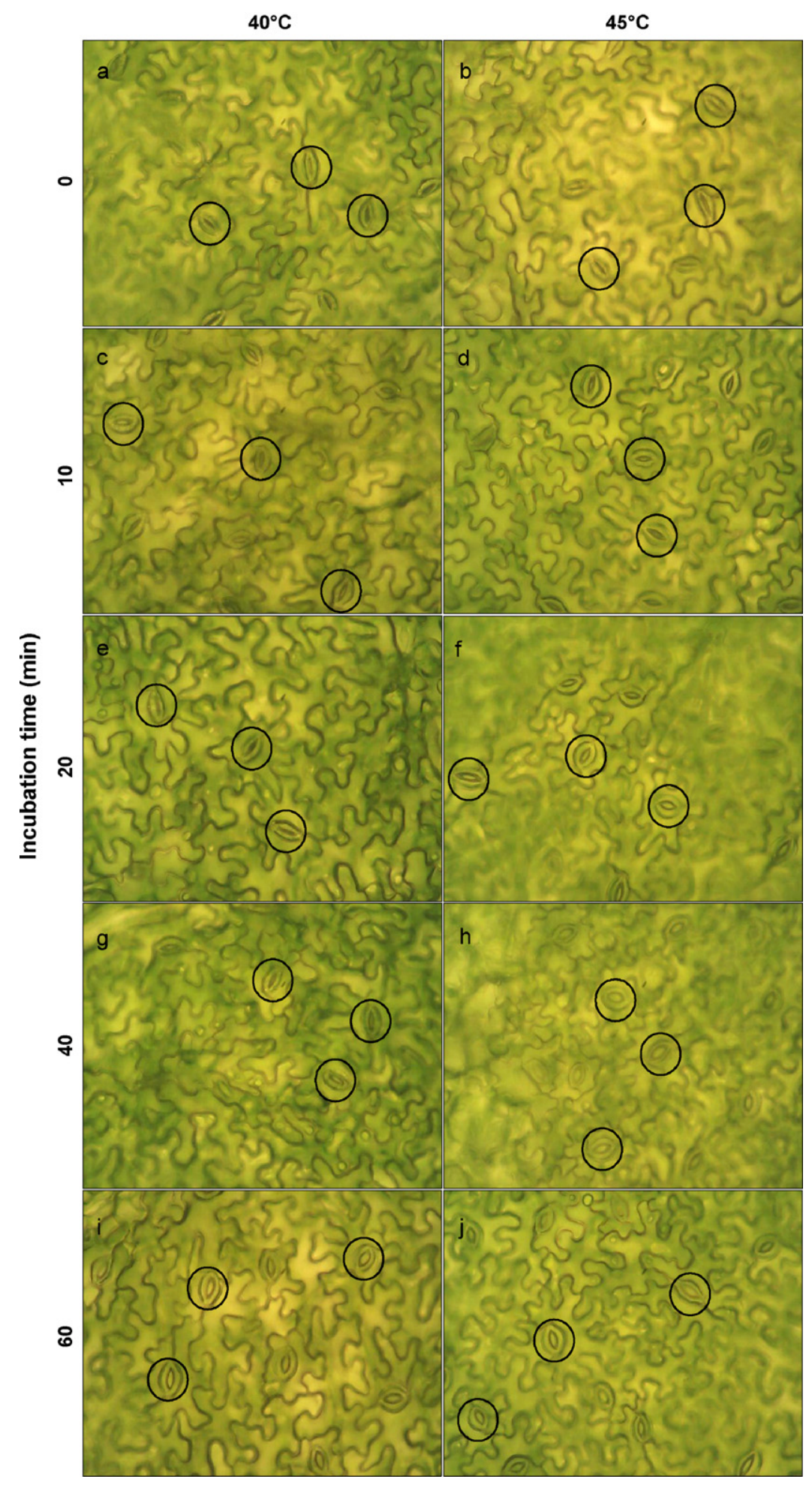

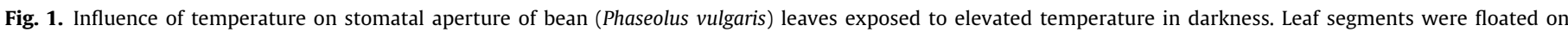
deionised water heated to indicated temperature for $0,10,20,40$ or $60 \mathrm{~min}$, then photographed. Some stomata are encircled for clarity. 
apparatus, is important in determining a plant's overall stress response.

\section{Materials and methods}

Dwarf bean (P. vulgaris L. Var. "Saxa”) and red clover (T. pratense) were germinated on wet paper and then grown hydroponically as reported previously (Hildbrand et al., 1994), in a growing room under day/night temperatures of $25 / 21^{\circ} \mathrm{C}$ and $130 \mu \mathrm{mol} \mathrm{m}^{-2} \mathrm{~s}^{-1}$ photosynthetically active radiation (PAR) during a $14 \mathrm{~h}$ photoperiod. Two-four weeks after germination, whole plants or primary leaf segments were used for the experiments.

In order to isolate the effect of short-term stress, hydroponic cultures were used, avoiding the additional influence on plant performance of nutrient stress, root exudation or impact of the rhizosphere. For the investigation of the impact of heat on stomatal opening, the potential confounding effects of drought or carbon assimilation on stomatal opening were eliminated by conducting experiments on liquid medium in darkness. Four leaves from 4 different plants (clover) or 6 leaves from 6 different plants (bean) were each divided into fragments $\left(0.2-0.5 \mathrm{~cm}^{2}\right)$, floated on deionised water, and heated to either 40 or $45^{\circ} \mathrm{C}$, in darkness, for $0,10,20$, 40 or $60 \mathrm{~min}$. Recovery occurred at room temperature during 120 (clover) or 60 (bean) minutes. A second series of four, 4-week-old bean leaf segments were pre-treated on nutrient medium with $(+)$ or without (-) $0.1 \mu \mathrm{M}$ abscisic acid (ABA), for $30 \mathrm{~min}$ at $23^{\circ} \mathrm{C}$, in darkness. Following pre-treatment, segments were transferred to deionised water heated to $23,30,35,40,45$ or $47^{\circ} \mathrm{C}$ for $20 \mathrm{~min}$. Following incubation, segments were transferred to deionised water at $23^{\circ} \mathrm{C}$ to recover for a period of $0,10,20$ or $30 \mathrm{~min}$. For each experiment, stomatal apertures were measured by placing leaf segments on a microscope slide and taking digital pictures focussed on the lower epidermis within $10 \mathrm{~s}$ (digital camera mounted on a microscope). All clearly visible stomata in the viewing field were measured and average opening calculated. Four separately incubated leaf segments were analyzed per treatment, each consisting of an average 19 stomata.

For the investigation of combined drought and temperature stress, $4 \%$ or $8 \%$ polyethylene glycol solution (PEG40 or PEG80, 40 or $80 \mathrm{~g}$ PEG-6000 in $1 \mathrm{~L}$ nutrient solution, respectively) was added to hydroponic cultures once plants were established, after 2 (bean) or 4 (clover) weeks. PEG simulates drought stress in plants by lowering the water potential in aqueous solution. The advantage of this type of stress over soil cultures is that it is: (1) rapidly achieved, (2) quantifiable, and (3) easily reproducible for different species, providing the homogeneous growth conditions needed to investigate basic response patterns in plants on relatively short timescales. Treatments consisted of nutrient solution + PEG (PEG), no nutrient solution (complete water deficit treatment, WD) or nutrient solution only (control). Different protocols for bean and clover allowed a broader range of conditions to be studied. Plants were treated for 2 (clover) or $72 \mathrm{~h}$ (bean), after which time different lighting regimes were imposed. The two different light sources consisted in a halogen (clover, PAR $=1600-1900 \mu \mathrm{mol} \mathrm{m}^{-2} \mathrm{~s}^{-1}$ ) and an infrared lamp (bean, PAR $=70 \mu \mathrm{mol} \mathrm{m}^{-2} \mathrm{~s}^{-1}$ ). Thermal images (thermal camera IRCON digiCAM-IR model 100PHT) were taken from the same position, with the help of a tripod, at given time intervals. To record the recovery process, the light source was shut off (resulting in PAR of $\left.2.5-4 \mu \mathrm{mol} \mathrm{m}-2 \mathrm{~s}^{-1}\right)$ and images were taken during the recovery period $(10 \mathrm{~min})$. An area on each thermal image, located at the centre of the main leaf and consisting of 220 pixels, was selected. Average temperature of all pixels of the selected area was calculated for each image, generating a single average leaf temperature per image. In addition, bean leaf response to PEG40 and infrared lighting was documented by thermal images taken at 1 -min intervals for 40 (treatment) and 21 (control; no PEG40) minutes.

\section{Results}

Heat led to stomatal opening (Figs. 1 and 2). Overall, stomatal opening was greater at $45^{\circ} \mathrm{C}$ than at $40^{\circ} \mathrm{C}$, and greater in bean than clover, with a maximum more than 2 times that of clover after $60 \mathrm{~min}$ incubation time. At the start of the experiment (incubation time of 0 ), stomatal opening was near 0 . In bean the increase in stomatal opening was progressive; in clover also, apart from a slight decrease in aperture from 50 to 60 min incubation at $45^{\circ} \mathrm{C}$ (Fig. 2). Regardless of incubation time, the effect of heat on stomata was reversible (Fig. 3): restoration of initial stomatal opening of ca. $0 \mu \mathrm{m}$ following heat stress occurred after $120 \mathrm{~min}$ for clover at $23^{\circ} \mathrm{C}$ and after $45 \mathrm{~min}$ at $23^{\circ} \mathrm{C}$ for bean.

An interaction between $A B A$ treatment and incubation temperature was observed in bean (Table 1 ). In the absence of $A B A$ $(-)$, stomatal opening at $23^{\circ} \mathrm{C}$ did not vary significantly. Increasing incubation temperature increased stomatal opening (recovery phase $0 \mathrm{~min}$ ) but this was quickly restored over time (recovery phase 10,20 and $30 \mathrm{~min}$ at $23^{\circ} \mathrm{C}$ ). A higher incubation temperature was required to initiate stomatal opening in the presence of $\mathrm{ABA}(+)$. Even at $47^{\circ} \mathrm{C}$, stomata were not fully opened. At 40 and $45^{\circ} \mathrm{C}$, the effect of ABA was significant $(p<0.05)$.

Leaf temperatures were deduced from thermal images of clover plants under high photosynthetically active radiation (PAR). Plants treated with PEG80 or complete water deficit (WD) showed higher leaf temperature than control (Fig. 4), though the effect was greater for WD plants (significant at $p<0.05$ for WD only). Pixel analysis revealed a maximum temperature of $33^{\circ} \mathrm{C}$ in WD plants after 30 min of illumination (Fig. 5). In control plants, leaf temperature initially decreased slightly followed by a progressive increase from 15 to $30 \mathrm{~min}$ incubation time. For PEG80 plants, a progressive decrease in leaf temperature (up to $15 \mathrm{~min}$ ) followed by an increase $(25 \mathrm{~min})$ followed by a decrease $(30 \mathrm{~min})$, was observed. For WD plants leaf temperature oscillations also occurred in the range of $30-33^{\circ} \mathrm{C}$. For the recovery in darkness, both PEG80 and control plants cooled quickly to ca. $22^{\circ} \mathrm{C}$, whereas WD plants maintained significantly higher leaf temperature for more than $1 \mathrm{~min}$ and leaf temperature only recovered after $10 \mathrm{~min}$ (Fig. 5). The return

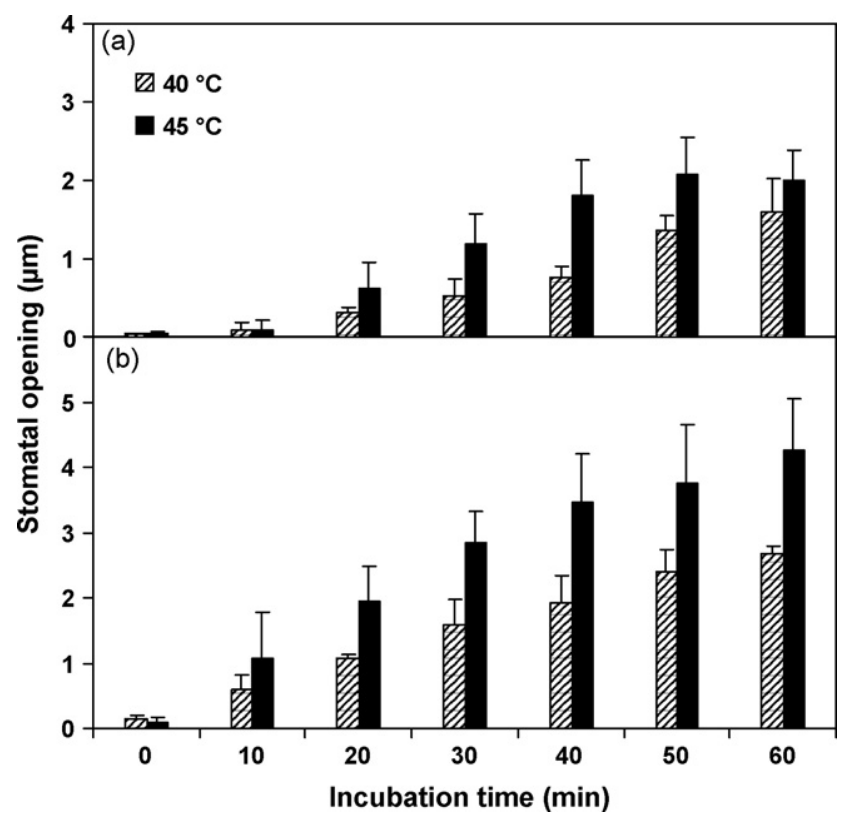

Fig. 2. Stomatal opening $(\mu \mathrm{m})$ of leaf segments of (a) clover (Trifolium pratense) and (b) bean (Phaseolus vulgaris) floated on water in darkness at 40 or $45^{\circ} \mathrm{C}$. Leaf segments were held at 40 or $45^{\circ} \mathrm{C}$ and stomatal opening was measured after 10, 20, 40 and 60 min. Means \pm SE of 4 (clover) or 6 (bean) independent samples are shown. 
Table 1

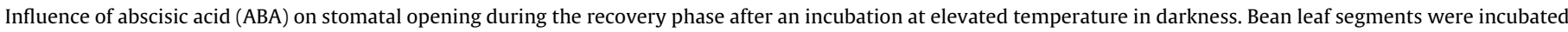

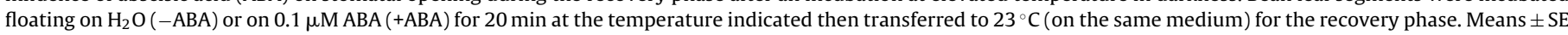
of 4 independent samples of stomatal diameter are shown $(\mu \mathrm{m})$.

\begin{tabular}{|c|c|c|c|c|c|}
\hline \multirow[t]{3}{*}{ Temperature $\left({ }^{\circ} \mathrm{C}\right)$} & \multirow[t]{3}{*}{$\mathrm{ABA}$} & \multicolumn{4}{|c|}{ Stomatal opening $(\mu \mathrm{m})$} \\
\hline & & \multirow[t]{2}{*}{ Initial } & \multicolumn{3}{|c|}{ Recovery phase at $23^{\circ} \mathrm{C}(\mathrm{min})$} \\
\hline & & & 10 & 20 & 30 \\
\hline 23 & - & $0.26 \pm 0.26$ & $0.17 \pm 0.11$ & $0.24 \pm 0.14$ & $0.52 \pm 0.24$ \\
\hline 30 & - & $1.85 \pm 0.33$ & $1.07 \pm 0.31$ & $0.24 \pm 0.16$ & $0.14 \pm 0.14$ \\
\hline 35 & - & $3.19 \pm 0.45$ & $1.16 \pm 0.52$ & $0.71 \pm 0.30$ & $0.78 \pm 0.58$ \\
\hline 40 & - & $3.05 \pm 0.41$ & $1.46 \pm 0.49$ & $0.35 \pm 0.22$ & $0.51 \pm 0.21$ \\
\hline 45 & - & $4.23 \pm 0.22$ & $1.92 \pm 0.60$ & $1.02 \pm 0.63$ & $0.44 \pm 0.44$ \\
\hline 40 & + & $0.10 \pm 0.10$ & 0 & 0 & 0 \\
\hline 45 & + & $1.01 \pm 0.32$ & $0.07 \pm 0.07$ & 0 & 0 \\
\hline 47 & + & $2.11 \pm 0.45$ & $1.30 \pm 0.50$ & $0.46 \pm 0.19$ & $0.32 \pm 0.12$ \\
\hline
\end{tabular}

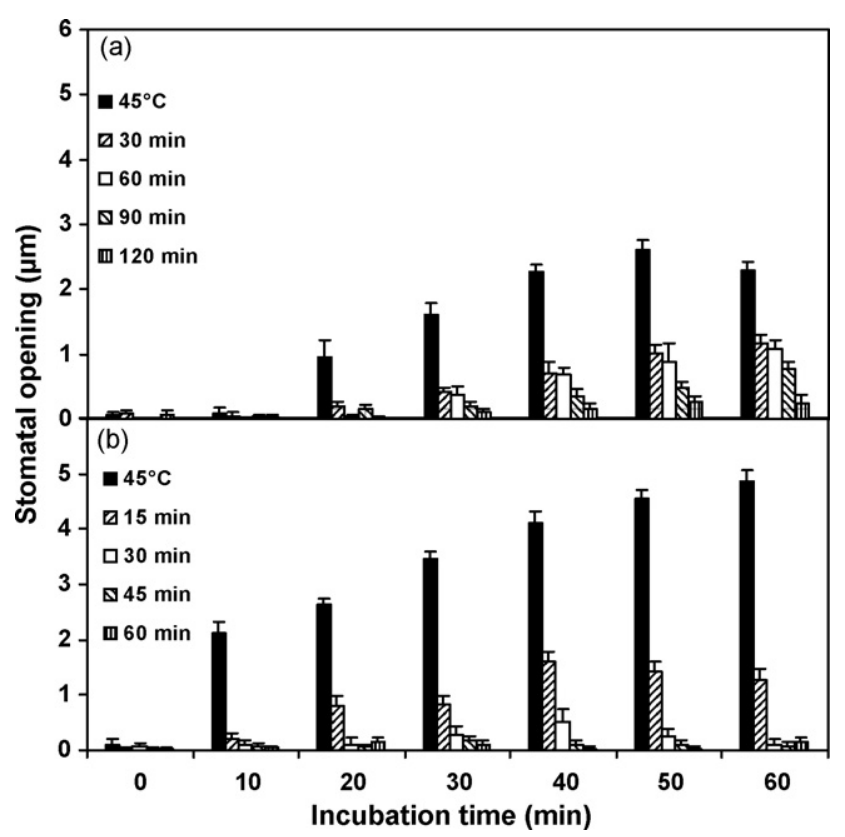

Fig. 3. Recovery of stomatal opening of leaf segments of (a) clover (Trifolium pratense) and (b) bean (Phaseolus vulgaris), following incubation of $0-60 \mathrm{~min}$ at $45^{\circ} \mathrm{C}$ in darkness. Recovery occurred at $23^{\circ} \mathrm{C}$ in darkness, and stomata were measured at $30,60,90$ and 120 min recovery from heat (clover) or 15, 30, 45 and 60 min recovery from heat (bean). Initial values after the heat treatment are shown with filled bars and the various recovery times with open or hatched bars as indicated in the figure. Means \pm SE of 4 (clover) or 6 (bean) independent samples are shown.

to pre-treatment leaf temperatures in darkness for WD plants was slower than for control and PEG80, requiring 10 min compared to $30 \mathrm{~s}$.

Temperature of bean leaves exposed to infrared light varied according to treatment. For control plants (Fig. 6a), leaf temperatures increased sharply from $31.8^{\circ} \mathrm{C}$ at $0.5 \mathrm{~min}$ to a maximum of $38^{\circ} \mathrm{C}$ after $4 \mathrm{~min}$, decreasing to $32^{\circ} \mathrm{C}$ over the next $10 \mathrm{~min}$ then increasing again to $35^{\circ} \mathrm{C}$ at $21 \mathrm{~min}$. For treatment (PEG40) plants (Fig. 6b) the opposite pattern was observed: leaf temperatures initially fell from 36 to $34^{\circ} \mathrm{C}$ (first $4 \mathrm{~min}$ ), then increased and remained in the range of $39-40{ }^{\circ} \mathrm{C}$ from 12 to $40 \mathrm{~min}$. In addition, leaf temperature was several degrees higher than in control plants at the onset of the experiment.

\section{Discussion}

The results of this study cannot completely describe the response of more mature or whole plants but they still show that under stress, plants experience a trade-off between preventing water loss and protection from over-heating. While hydroponic cultures do not represent natural growing conditions, this technique allowed us to grow plants with identical pre-experimental growth conditions, with a set-up that is easily reproducible, and for a large number of plants and species. The use of leaf segments floating on water in darkness helped exclude the effects of carbon fixation, water status and transpiration on stomatal opening. The use of two different light sources allowed separation of the effect of high heat stress (infrared light) from strong photosynthetically active radiation (halogen light) on stomatal opening. Bean stomata appeared somewhat more responsive to heat stress than clover (timing, magnitude and speed of initial response and recovery). While absolute responses are species-specific, similar trends were observed for the two legume species considered.

Heat stress led to increased stomatal opening (measured). In general, highly variable leaf temperatures and stomatal opening within the relatively short intervals studied illustrates the high stomatal sensitivity to change. The more pronounced opening at $45^{\circ} \mathrm{C}$ compared to $40^{\circ} \mathrm{C}$ was also observed in whole leaves of field-grown Trifolium repens plants (not shown), indicating that this response probably occurs regardless of culture and/or treatment. In addition, the range of observed leaf temperatures under stress was attributed to changes in stomatal opening, a dependency shown for other studies, regardless of $\mathrm{CO}_{2}$ assimilation status (Feller, 2006). Concerning leaf temperature pattern, control plants under constant and low PAR showed leaf temperature fluctuations between 32 and $38^{\circ} \mathrm{C}$ for a period of $21 \mathrm{~min}$. Similar fluctuations were observed by Feller (2006) for non-stressed bean plants exposed to infrared light for $30 \mathrm{~min}$. However, drought-stressed plants under otherwise identical conditions showed a unidirectional response: progressive increase in leaf temperature to $40^{\circ} \mathrm{C}$ over $12 \mathrm{~min}$ (attributed to progressive stomatal closure), then temperature stability up to $40 \mathrm{~min}$. For the experiment at high PAR, leaf temperatures were lower than at low PAR, reflecting light source properties. Control plants showed temperatures within a range of $1^{\circ} \mathrm{C}$. However, pronounced temperature fluctuations $\left( \pm 2^{\circ} \mathrm{C}\right)$ were observed for leaves in the complete absence of water (WD), showing warming followed by cooling, followed by further warming. Leaves under PEG treatment exhibited temperatures closer to values for control plants but with fluctuations within a $5{ }^{\circ} \mathrm{C}$ range. Similarly, Haefner et al. (1997) found that stomata exhibit homogeneous behaviour at high humidity (control) and patchy oscillatory behaviour at low humidity (stress). Our results show that combined heat and drought stress alters the leaf response in order to maintain favourable leaf temperature. Overall, regardless of lighting type, the stomatal response to heat or combined heat and drought was fully reversible over time in whole plants (leaf temperatures decreasing to $22^{\circ} \mathrm{C}$ for all treatments).

Concerning timing of stomatal response, under infrared lighting, stomatal adjustment to stress occurred within the first 4 min. After 


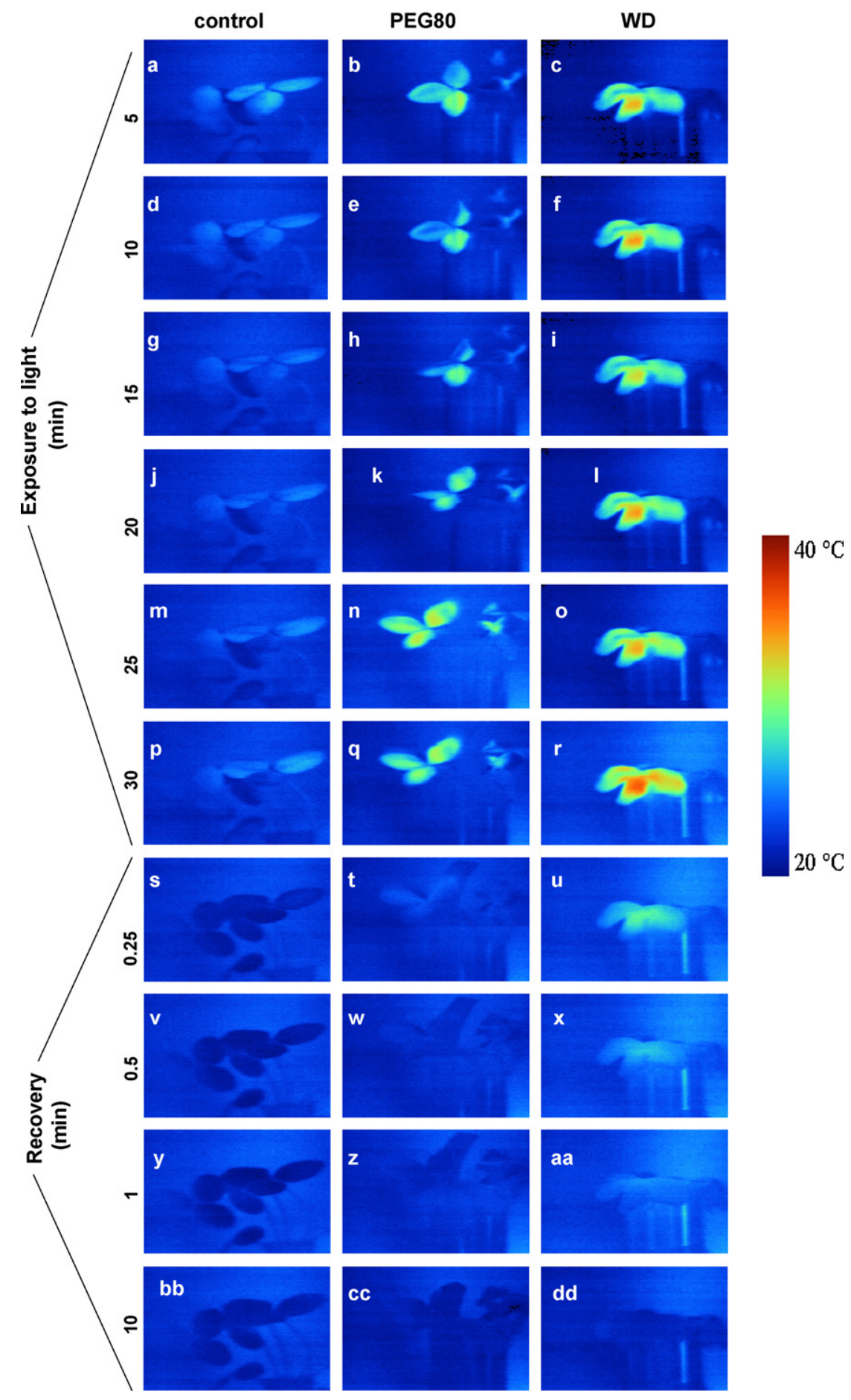

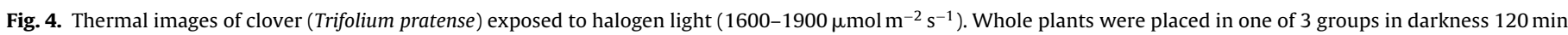

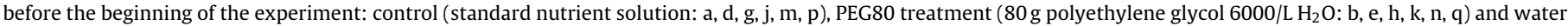

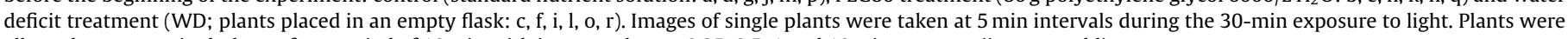
allowed to recover in darkness for a period of $10 \mathrm{~min}$ with images taken at $0.25,0.5,1$ and 10 min recovery (images s-dd).

4 min, plants began either cooling (control, Fig. 6a) or warming (PEG40, b). In Feller (2006), steady leaf temperatures were achieved in bean leaves exposed to an infrared lamp only after the same 4-min delay for bean plants transferred from darkness to either halogen or infrared lighting. This illustrates that while changes in external conditions may be sudden, it takes several minutes for the stomatal response to be perceptible. The delay appears to be similar in legumes regardless of the exact nature of the study conducted or the stress applied.
ABA, a phytohormone accumulated rapidly in the leaf during drought stress, typically causes a decrease in stomatal aperture and transpiration rate (Iriti et al., 2009). At $40^{\circ} \mathrm{C}$, a temperature often achieved by sun-exposed leaves in the field (Feller, 2006), plants treated with ABA showed lower stomatal conductance than control. Despite the influence of $A B A$, stomata were partially open when temperature was increased to 45 or $47^{\circ} \mathrm{C}$, remaining open during the recovery phase at $23^{\circ} \mathrm{C}(30 \mathrm{~min})$. During this phase stomata closed within $10 \mathrm{~min}$ following the $40^{\circ} \mathrm{C}$ treatment, but remained 


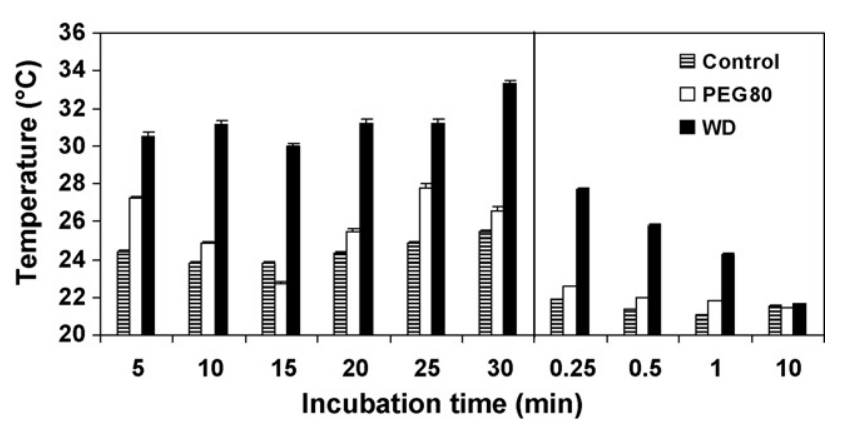

Fig. 5. Average pixel temperature of selected clover (Trifolium pratense) leaf area of thermal images featured in Fig. 4 ( $n=220$ pixels) for either control (standard nutrient solution), PEG80 ( $80 \mathrm{~g}$ polyethylene glycol $6000 / \mathrm{L} \mathrm{H}_{2} \mathrm{O}$ ) or WD (water deficit) treatments. Temperatures represent average leaf temperatures of clover plants (Trifolium pratense) (determined at 5 min intervals from 0 to $30 \mathrm{~min}$ ) exposed to halogen light (1600-1900 $\mu \mathrm{mol} \mathrm{m}^{-2} \mathrm{~s}^{-1}$ ) for $30 \mathrm{~min}$ (left of vertical line), followed by average leaf temperatures during recovery (right of vertical line) in darkness at $23^{\circ} \mathrm{C}$ (determined at $0.25,0.5,1$ and $10 \mathrm{~min}$ ), $\pm \mathrm{SE}$.

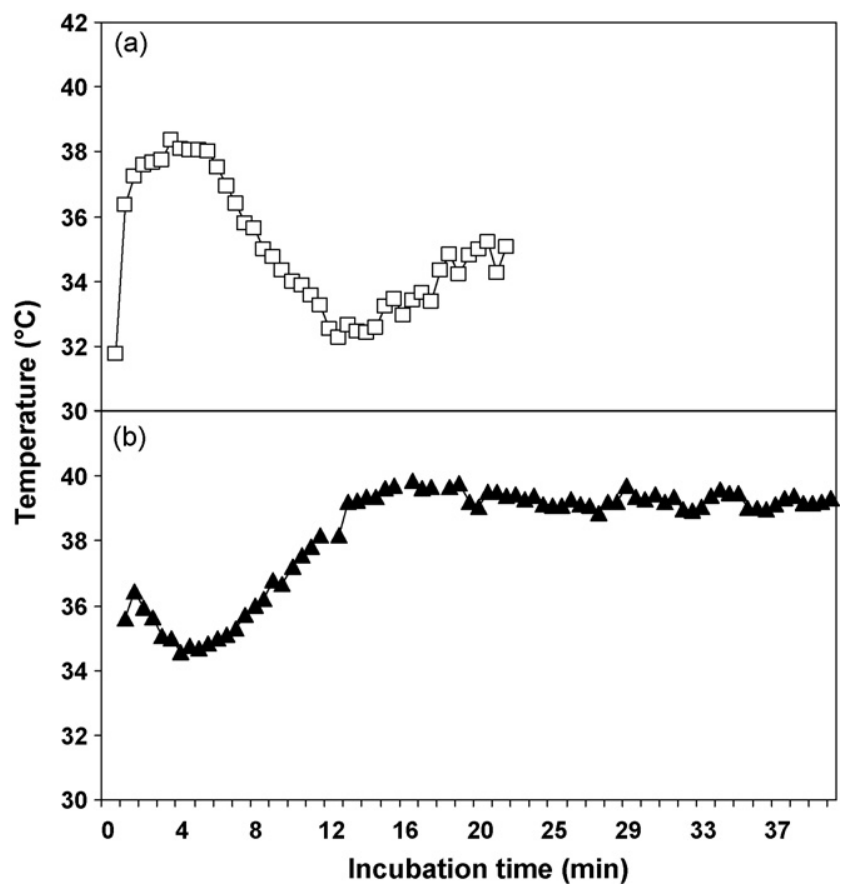

Fig. 6. Average pixel temperature of selected bean (Phaseolus vulgaris) leaf area of thermal images ( $n=220$ pixels). Treatment plants were treated with PEG40 (40 g polyethylene glycol $6000 / \mathrm{L} \mathrm{H}_{2} \mathrm{O}$ ) for $72 \mathrm{~h}$. All plants were then exposed to heat from an infrared light ( $\left.70 \mu \mathrm{mol} \mathrm{m}^{-2} \mathrm{~s}^{-1}\right)$ and images taken at 1 -min intervals for $21 \mathrm{~min}$ ((a), control; no PEG40) or 40 min ((b), PEG40 treatment).

open for as long as $30 \mathrm{~min}$, following the $47^{\circ} \mathrm{C}$ treatment. This illustrates a shift in the stomatal response (stomata opening to cool leaf) to a higher temperature, under stress.

Though the exact mechanism of temperature sensing in stomata remains open, metabolic changes and membrane properties could explain the apparent differences in responses observed under the range of conditions studied. Overall, high stomatal sensitivity to external conditions (wide range of stomatal response) was demonstrated.

\section{Conclusion}

Changes in stomatal opening are a primary, rapidly occurring effect of drought and heat stress in legumes. Previously, elevated temperatures were shown to negatively affect photo- synthesis (Feller et al., 1998; Law and Crafts-Brandner, 1999; Haldimann and Feller, 2004), influencing leaf metabolism primarily through Rubisco activase properties and Rubisco activation state (Feller et al., 1998; Crafts-Brandner and Salvucci, 2000; Haldimann and Feller, 2004, 2005). It was also demonstrated that plants increase stomatal conductance under high temperatures (Salvucci and Crafts-Brandner, 2004). However, our results show that stomatal response to heat and drought is complex: legumes respond to moderate stress by closing stomata or causing irregular conductance and to high temperature stress by increasing stomatal conductance, even under drought. While the response to moderate overall stress indicates a tendency to prioritize water relations, the response to higher stress suggests that metabolic effects pertaining to the protection of the photosynthetic apparatus from heat, are limiting. Globally, stomata are responsible for the flow of $\mathrm{CO}_{2}$ fixed and water lost by plants. Further characterizing stomatal responses to stress will have many applications from modelling energy fluxes to determining ecosystem responses or individual plant survival in a future climate.

\section{Acknowledgement}

This work was supported by the NCCR Climate (Project PLANT/SOIL).

\section{References}

Assmann, S.M., Shimazaki, K., 1999. The multisensory guard cell. Stomatal responses to blue light and abscisic acid. Plant Physiol. 119, 809-815.

Chaves, M.M., Pereira, J.S., Maroco, J., Rodrigues, M.L., Ricardo, C.P.P., Osorio, M.L., Carvalho, I., Faria, T., Pinheiro, C., 2002. How plants cope with water stress in the field. Photosynthesis and growth. Ann. Bot. 89, 907-916

Ciais, P., Reichstein, M., Viovy, N., Granier, A., Ogée, J., Allard, V., Aubinet, M., Buchmann, N., Bernhofer, C., Carrara, A., Chevallier, F., De Noblet, N., Friend, A.D., Friedlingstein, P., Grünwald, T., Heinesch, B., Keronen, P., Knohl, A., Krinner, G., Loustau, D., Manca, G., Matteucci, G., Migiletta, F., Ourcival, J.M., Papale, D., Pilegaard, K., Rambal, S., Seufert, G., Soussana, J.F., Sanz, M.J., Schulze, E.D., Vesala T., Valentini, R., 2005. Europe-wide reduction in primary productivity caused by the heat and drought in 2003. Nature 437,529-533.

Crafts-Brandner, S.J., Salvucci, M.E., 2000. Rubisco activase constrains photosynthetic potential of leaves at high temperature and $\mathrm{CO}_{2}$. Proc. Natl. Acad. Sci. U.S.A. 97, 13430-13435.

Eamus, D., Fenton, R., Wilson, J.M., 1982. Stomatal behaviour and water relations of chilled Phaseolus vulgaris L. and Pisum sativum L. J. Exp. Bot. 34 (141), 434-441.

Feller, U., 2006. Stomatal opening at elevated temperature: an underestimated regulatory mechanism? Gen. Appl. Plant Physiol. XXXII, 19-31 (special issue).

Feller, U., Crafts-Brandner, S.J., Salvucci, M.E., 1998. Moderately high temperatures inhibit ribulose-1,5-biphosphate carboxylase/oxygenase (Rubisco) activasemediated activation of Rubisco. Plant Physiol. 116, 539-546.

Flexas, J., Bota, J., Loreto, F., Cornic, G., Sharkey, T.D., 2004. Diffusive and metabolic limitations in photosynthesis under drought and salinity in C3 plants. Plant Biol. 6, 269-279.

Fuchs, M., Tanner, C.B., 1966. Infrared thermometry of vegetation. Agron. J. 58 597-601.

Gates, D.M., 1964. Leaf temperature and transpiration. Agron. J. 56, 273-277.

Grassi, G., Magnani, F., 2005. Stomatal, mesophyll conductance and biochemical limitations to photosynthesis as affected by drought and leaf ontogeny in ash and oak trees. Plant Cell Environ. 28, 834-849.

Haefner, J.W., Buckley, T.N., Mott, K.A., 1997. A spatially explicit model of patchy stomatal responses to humidity. Plant Cell Environ. 20, 1087-1097.

Haldimann, P., Feller, U., 2004. Inhibition of photosynthesis by high temperature in oak (Quercus pubescens L.) leaves grown under natural conditions closely correlates with a reversible heat-dependent reaction of the activation state of ribulose-1,5-biphosphate carboxylase/oxygenase. Plant Cell Environ. 27, 1169-1183.

Haldimann, P., Feller, U., 2005. Growth at moderately elevated temperature alters the physiological response of the photosynthetic apparatus to heat stress in pea (Pisum sativum) leaves. Plant Cell Environ. 28, 302-317.

Hildbrand, M., Fischer, A., Feller, U., 1994. Protein catabolism in bean leaf discs: accumulation of a soluble fragment of ribulose-1,5-bisphosphate carboxylase/oxygenase under oxygen deficiency. J. Exp. Bot. 45, 1197-1204.

Iriti, M., Picchi, V., Rossoni, M., Gomarasca, S., Ludwig, N., Gargano, M., Faoro, F., 2009 Chitosan antitranspirant activity is due to abscisic acid-dependent stomatal closure. Environ. Exp. Bot. 66, 493-500.

Jones, H.G., 1992. Plants and Microclimate, second ed. Cambridge University Press.

Kappen, L., Andresen, G., Loesch, E., 1987. In situ observations of stomatal movements. J. Exp. Bot. 38, 126-141. 
Law, R.D., Crafts-Brandner, S.J., 1999. Inhibition and acclimation of photosynthesis to heat stress is closely correlated with activation of ribulose-1,5-biphsophate carboxylase-oxygenase. Plant Physiol. 120, 173-181.

Lawson, T., 2009. Guard cell photosynthesis and stomatal function. New Phytol. 181, $13-34$.

Lu, Z., Quinones, M.A., Zeiger, E., 2000. Temperature dependence of guard cell respiration and stomatal conductance co-segregate in an $F_{2}$ population of Pima cotton. Aust. J. Plant Physiol. 27, 457-462.

Machado, S., Paulsen, G.M., 2001. Combined affects of drought and high temperature on water relations of wheat and sorghum. Plant Soil 233, 179-187.

Medlyn, B.E., Barton, C.V.M., Broadmeadow, M.S.J., Ceulemans, R., De Angelis, P., Forsteuter, M., Freeman, M., Jackson, S.B., Kellomäki, S., Laitat, E., Rey, A., Roberntz, P., Sigurdsson, B.D., Strassenmeyer, J., Wang, K., Curtis, P.S., Jarvis, P.G., 2001. Stomatal conductance of forest species after long-term exposure to elevated $\mathrm{CO}_{2}$ concentration: a synthesis. New Phytol. 149, 247-264.

Meehl, G.A., Tebaldi, C., 2004. More intense, more frequent and longer-lasting heat waves in the 21st century. Science 305, 994-997.

Morison, J.I.L., Gifford, R.M., 1984. Plant-growth and water-use with limited water supply in high $\mathrm{CO}_{2}$ concentrations. 1. Leaf-area, water-use and transpiration. Aust. J. Plant Physiol. 11, 361-374.

Mott, K.A., Denne, K., Powell, J., 1997. Interaction among stomata in response to perturbations in humidity. Plant Cell Environ. 20, 1098-1107.

Pachepsky, Y.A., Guber, A.K., Jacques, A., 2005. Temporal persistence in vertical distributions of soil moisture contents. Soil Sci. Soc. Am. J. 69 (2), 347-352.

Radin, J.W., Lu, Z., Pichard, R.G., Zeiger, E., 1994. Genetic variability for stomatal conductance in Pima cotton and its relation to improvement of heat adaptation. Proc. Natl. Acad. Sci. U.S.A. 91, 7217-7221.

Roelfsema, M.R.G., Hanstein, S., Felle, H.H., Hedrich, R., 2002. $\mathrm{CO}_{2}$ provides an intermediate link in the red light response of guard cells. Plant J. 32, 65-75.

Saxe, H., Ellsworth, D.S., Heath, J., 1998. Tree and forest functioning in an enriched $\mathrm{CO}_{2}$ atmosphere. New Phytol. 139, 395-436.

Salvucci, M.E., Crafts-Brandner, S.J., 2004. Inhibition of photosynthesis by heat stress: the activation state of Rubisco as a limiting factor in photosynthesis. Physiol. Plant 120, 66-71.
Schär, C., Vidale, P.L., Lüthi, D., Frei, C., Häberli, C., Liniger, M.A., Appenzeller, C., 2004 The role of increasing temperature variability in European summer heatwaves. Nature 427, 332-335.

Shah, N.H., Paulsen, G.M., 2003. Interaction of drought and high temperature on photosynthesis and grain-filling of wheat. Plant Soil 257, 219-226.

Smith, R.C.G., Barrs, H.D., Fisher, R.A., 1988. Inferring stomatal resistance of sparse crops from infrared measurement of foliage temperature. Agric. Forest. Met. 42, 183-198.

Teuling, A.J., Hupet, F., Uijlenhoet, R., Troch, P.A., 2007. Climate variability effects on spatial soil moisture dynamics. Geophys. Res. Lett. 34, L06406.

Van Peer, L., Nijs, I., Reheul, D., De Cauwer, B., 2004. Species richness and susceptibility to heat and drought extremes in synthesized grassland ecosystems: compositional vs. physiological effects. Funct. Ecol. 18, 69-778.

Veselova, S.V., Farkhutdinov, R.G., Veselov, D.S., Kudoyarova, G.R., 2006. Role of cytokinins in the regulation of stomatal conductance of wheat seedlings under conditions of rapidly changing local temperature. Russ. J. Plant Physiol. 53 (6), 756-761.

Wang, Z., Huang, B., 2004. Physiological recovery of Kentucky bluegrass from simultaneous drought and heat stress. Crop Sci. 44, 1729-1736.

Wardlaw, I.F., 2002. Interaction between drought and chronic high temperature during kernel filling in wheat in a controlled environment. Annal. Bot. 90, 469-476.

Wilkinson, S., Clephan, A.L., Davies, W.J., 2001. Rapid Low temperature-induced stomatal closure occurs in cold-tolerant Commelina communis leaves but not in cold-sensitive tobacco leaves, via a mechanism that involves apoplastic calcium but not abscisic acid. Plant Physiol. 126, 1566-1578.

Wilkinson, S., Davies, W.J., 2002. ABA-based chemical signalling: the coordination of responses to stress in plants. Plant Cell Environ. 25, 195-210.

Wong, S.C., Cowan, I.R., Farquhar, G.D., 1979. Stomatal conductance correlates with photosynthetic activity. Nature 282, 424-426.

Zeiger, E., 1983. Biology of stomatal guard cells. Annu. Rev. Plant Physiol. 34, 441-475.

Zeiger, E., Field, C., 1982. Photocontrol of the functional coupling between stomatal conductance in the intact leaf. Plant Physiol. 70, 370-375. 